AC ANNALS JOURNAL CLUB

\title{
Communities of Solution
}

Ann Fam Med 2012;10:iii. doi:10.1370/afm.1414.

$\mathrm{T}$ The Annals of Family Medicine encourages readers to develop a learning community of those seeking to improve health care and health through enhanced primary care. You can participate by conducting a RADICAL journal club and sharing the results of your discussions in the Annals online discussion for the featured articles. RADICAL is an acronym for Read, Ask, Discuss, Inquire, Collaborate, Act, and Learn. The word radical also indicates the need to engage diverse participants in thinking critically about important issues affecting primary care and then acting on those discussions. ${ }^{1}$

\section{HOW IT WORKS}

In each issue, the Annals selects an article or articles and provides discussion tips and questions. We encourage you to take a RADICAL approach to these materials and to post a summary of your conversation in our online discussion. (Open the article online and click on "TRACK Comments: Submit a response.") You can find discussion questions and more information online at: http://www.AnnFamMed.org/AJC/.

\section{CURRENT SELECTION}

\section{Article for Discussion}

The Folsom Group. Communities of solution: the Folsom Report revisited. Ann Fam Med. 2012;10(3):250-260.

\section{Discussion Tips}

This article provides an opportunity to reinvent the insights of an influential report to guide the actions of family physicians, community partners, policy makers, and others toward sustainably achieving healthy communities.

\section{Discussion Questions}

- What is the Folsom Report?2

- How are the challenges addressed by the Folsom Report in 1967 (providing more comprehensive health care, improving the social and environmental determinants of health, enhancing urban and rural life...) relevant today?

- What current forces favor acting now on the Community of Solution vision?

- What health problems are best addressed at the level of community?

- How can a community focus complement a focus on caring for individual patients to promote health?

- Discuss the current report's "grand challenges."

- How can activities and policies at the federal and state levels complement action at the local community level to promote health?

- Although the Institute of Medicine defines primary care as being provided "in the context of community, $^{113}$ does the Community of Solution concept give you a way of acting on this ideal?

- How can working toward communities of solution become part of your professional and personal identities? What training and support systems are needed to make this a reality?

- How might you begin working to create communities of solution where you live and work? ${ }^{4}$

\section{References}

1. Stange KC, Miller WL, McLellan LA, et al. Annals Journal Club: It's time to get RADICAL. Ann Fam Med. 2006;4(3):196-197. http:// annfammed.org/content/4/3/196.full.

2. Folsom MB. American Public Health Association and National Health Council. Health is a Community Affair. Report of the National Commission on Community Health Services. Boston, MA: Harvard University Press; 1967.

3. Donaldson MS, Yordy KD, Lohr KN, Vanselow NA, eds. Primary Care: America's Health in a New Era. Washington, DC: National Academies Press; 1996.

4. Thomas P. Integrating Primary Health Care: Leading, Managing, Facilitating. Oxford, UK: Radcliffe Publishing; 2006. 